\title{
Stopcock Valve Device
}

National Cancer Institute

\section{Source}

National Cancer Institute. Stopcock Valve Device. NCI Thesaurus. Code C50333.

A rotating valve designed to regulate the flow of a fluid through a stopcock. 